\title{
İstanbul Borsası'nda İşlem Gören Firmaların Finansal Performanslarının Kümeleme Analizi ile Değerlendirilmesi
}

\author{
Emin Sertaç ARI, Hakan ÖZKÖSE, Ahmet DOĞAN, M. Hanefi CALP \\ Yönetim Bilișim Sistemleri Anabilim Dalı, Bilişim Enstitüsü, Gazi Üniversitesi, Ankara, Türkiye \\ sertacari@gazi.edu.tr, hakanozkose@ gazi.edu.tr, ahmetdogan@ osmaniye.edu.tr, mhcalp@ gazi.edu.tr \\ (Gelis/Received: 12.03.2015; Kabul/Accepted: 24.10.2015) \\ DOI: $10.17671 / \mathrm{btd} .55726$
}

\begin{abstract}
$\ddot{O}_{z}$ et- Firmalar içinde bulundukları sektörlere göre birtakım faaliyetler gerçekleştirmektedir. Bu faaliyetlerinin dökümü olan finansal tablolar ise firmalara geçmiş faaliyet dönemi hakkında fikir vermekte, sonraki dönemler için atacağı adımları ve alacağı tedbirleri şekillendirmektedir. Gelişen bilişim teknolojileri kullanıcılarına çok büyük veriler üzerinde son derece önemli analizler yapma imkânı tanımaktadır. Bu analizler sayesinde firmalar mevcut duruma dair görüntüler elde etmekte, geleceğe dair senaryolar üretmekte ve gelecek projeksiyonlarını bu veriler 1șığında şekillendirebilmektedirler. Bu çalışma kapsamında Borsa İstanbul (BİST)'da işlem gören 90 adet firmanın 2013 yılına ait finansal tabloları üzerinden çalışma kapsamında belirlenmiş olan finansal oranlarının hibrid bir veri madenciliği yöntemi olan İki Aşamalı Kümeleme Analizi yöntemi ile performanslarının incelenmesi amaçlanmıştır. Çalışma kapsamında uygulanan üç farklı analizden ilk uygulamada 12 faktör ve 90 birimden oluşan matris iki aşamalı kümeleme analizine alınmış, sonuçta küme kalitesi orta derecede olan iki adet küme elde edilmiştir. İkinci uygulamada veri seti varyans analizine tabi tutularak faktörlerden birimler için istatistiksel olarak anlamlı farklılık arz etmeyen 5 faktör elenmiş, iki aşamalı kümeleme uygulaması elde kalan 7 faktör üzerinden yapılmıştır. Burada küme kalitesi oldukça yüksek olan yine iki küme elde edilmiştir. Üçüncü uygulamada ise daha önceki uygulamalarda eleman sayısı çok yüksek olan küme ayrıştırmak istenmiş, sonuçta 3 kümeli ancak kalitesi biraz daha düşük bir sonuç elde edilmiştir.
\end{abstract}

Anahtar Kelimeler — Finansal oran, veri madenciliği, kümeleme analizi, iki aşamalı kümeleme.

\section{Interpretation of the Financial Performances of the Listed Firms on İstanbul Stock Exchange with Clustering Analysis}

\begin{abstract}
Firms have some activities within their industries. The financial tables which represent the inventories of these activities provide insight about their operating cycles, shape their actions and precautions to be taken. Developing information technologies enable the users make important analyses on huge amount of data. By means of these analyses; namely data mining; firms have the opportunity to see their current situations, to produce future scenarios and to shape their projections in consideration of these data. With this study it is aimed to research the performances of selected 90 firms that are traded at İstanbul Stock Exchange with two step clustering analysis which is a hybrid data mining technique, over the financial ratios determined on their financial tables of 2013 operating cycle. Among the three analyzes applied within the study, by the first one a matrix with 12 factors and 90 units was analyzed and two clusters were generated with medium quality. By the second analyze, the data set was put to variance analyze to eliminate the factors which are statistically not different. In the end, the two step clustering analysis was applied over the remaining 7 factors and again two clusters were generated with relatively high cluster quality. By the third analyze the huge cluster at the former analyze was tried to be separated and three clusters were generated with a lower cluster quality.
\end{abstract}

Keywords - Financial ratio, data mining, clustering analysis, two step clustering. 


\section{GİRIŞ (INTRODUCTION)}

Firmalar faaliyetlerini yürütebilmek ve büyüyebilmek için kaynağa ihtiyaç duymaktadırlar. Bunu ya yabancı kaynaklardan borç alarak ya da firmanın ortaklarından veya kâr aktarımı yoluyla, yani öz kaynaklardan sermaye yoluyla edinebilirler. Her iki kaynak edinme şeklinde de firmalar yabancı kaynaklar için faiz ödeme, öz kaynaklar için ise temettü dağıtma gibi birtakım yükümlülükler altına girmek zorunda kalmaktadırlar. Firmalar bu yöntemlerden maliyeti düşük olanı tercih etmektedirler. Eğer öz kaynak yoluyla fonlamanın maliyeti daha düşükse firmalar halka arz yoluna gidebilirler. Türkiye'de yürürlükte olan vergi mevzuatının da halka açık firmalara ciddi vergi indirimleri getirmesi, halka arzı firmalar açısından cazip hale getirmektedir. Halka arzın sağladığı bir diğer avantaj da firmalara tanınırlık sağlaması, bu yolla firmada bir değer oluşturması ve bu değerin karşılaştırmalı performans ölçütü olarak kullanılabilmesidir [1]. Genel olarak bir firmayı (hisse senedini) değerlerken kullanılacak üç temel bilgi kaynağı vardır. Bunlar; cari yıla ait firma mali tabloları, firma geçmişine ait bilgiler ve firmanın bulunduğu sektördeki rakiplerinin mali verilerdir [2].

Bu çalışmanın amacı bir hibrid kümeleme analizi yöntemi olan İki Aşamalı Kümeleme yöntemi ile Borsa İstanbul'da işlem gören 90 adet firmanın, kamuya açık finansal tablolarından belirlenmiş olan finansal oranlarının ait olduğu kümeyi görmektir. Bu bağlamda hangi firmanın hangi kümede olduğunu görerek, finansal durumun bir yansimasi olan finansal oranlar ile ne durumda olduklarını anlamaya yardımeı olmaktır.

Çalıșmanın ikinci bölümünde Finansal Oran Analizi anlatılmakta, üçüncü bölümünde, çalışmada uygulanan İki Aşamalı Kümeleme Analizinden bahsedilmektedir. Dördüncü bölümde uygulama anlatılmakta, beșinci bölümde bulgulara yer verilmekte, altıncı bölümde de sonuç ve öneriler sunulmaktadır.

\section{FINANSAL ORAN ANALIZİ (FINANCIAL RATIO ANALYSIS}

Y1l içerisinde faaliyetlerini gerçekleştiren firmalar yılsonunda faaliyet raporlarını finansal tablolar aracılı̆g 1 ile ilgililere sunarlar. Bu tablolardan birtakım finansal analizler yapılmaktadır. Finansal tabloların amacı, bir işletmenin faaliyetleri ve içinde bulunduğu durum hakkında dış dünyaya bilgi vermektir. Başka bir deyişle, çeşitli finansal tablo kullanıcılarına, ekonomik kararlar verirken faydalanmaları için işletmenin finansal durumu, performansı (faaliyet sonuçları) ve finansal durumundaki değişiklikler hakkında bilgi sağlamaktır [3, 4]. Finansal tablolar aracılığıyla sunulan bilgilerin, üçüncü kişilerin ve özellikle yatırımcıların karar almalarına yardımcı olacak şekilde doğru, anlaşılır, güvenilir ve karşılaştırılabilir olmas1, ayrıca finansal bilgiden beklenen faydanın arttırılması belirgin bir şekilde öne çıkmıştır [5, 6].

İşletmelerin finansal durumu, kârlılığı ve verimliliği değerlendirilirken; işletmelerin finansal tablolarında yer alan mutlak rakamlar değil, bu rakamlar arasındaki oranlar karar alma sürecinde daha çok anlam ifade etmektedir. Dolayssiyla oran analizi ile birbiriyle bağlantılı kalemler arasındaki ilişkiyi ortaya koymak mümkün hale gelmektedir [7].

Oran analizi, genellikle bir işletmede finansal analizin gerçekleştirilmesi aşamasındaki ilk adım olarak kabul edilmektedir. Finansal tablolarda yer alan çeşitli kalemlerin birbirine oranlanmasıyla, işletmeler arasında finansal durum karşılaştırması yapılabilmektedir [8, 9]. Finansal oranlar tek başlarına herhangi bir anlam ifade etmemekte, işletmelerin geçmiş döneme ait oranları ile veya diğer işletmelerin oranlarıyla karşılaştırılmaları durumunda isabetli sonuçlar elde etmek ve bir analiz yapabilmek mümkün hale gelmektedir [10].

Oran analizi yapılırken önemli olan çok sayıda oran hesaplayarak rakamlar yığını meydana getirmek değil, amaca uygun oranlarlar belirleyerek işletmenin likidite, mali yap1, verimlilik ve borç ödeyebilme gücünü açılayacak oranların seçilmesidir [11]. Bu noktada oluşturulacak oranlara literatürde de kabul görmüş şekli ile likidite, faaliyet, mali yapı ve karlılık oranları olmak üzere dört grupta sınıflandırma yapmak mümkündür [10].

\section{3. İKI AŞAMALI KÜMELEME ANALIZİ (TWO STEPS CLUSTERING ANALYSIS)}

Çok değişkenli analiz tekniklerinden biri olan kümeleme analizinin öncelikli amacı, birey ya da nesnelerin temel özelliklerini dikkate alarak onları gruplandırmaktır. Diğer bir deyişle kümeleme analizi, gruplanmamış verileri benzerliklerine göre gruplandırarak araştırmacıya özet bilgiler sunmaktır [12]. Kümeleme analizi neticesinde küme içi birimler, kümeler arasındaki birimlere göre karakteristik özellikleri bakımından daha çok benzeşirler. Bunun sonucu olarak da, küme içi homojenlik, kümeler arası heterojenlik sağlanmış olur [13].

Kümeleme Analizi temelde Hiyerarşik Kümeleme ve Hiyerarşik Olmayan Kümeleme olarak iki gruba ayrılmaktadır. Hiyerarşik kümeleme yönteminde, gruplayıcı (agglomerative) ve parçalayıcı (divisive) olmak üzere iki ana teknik vardır. Her birimin başlangıçta bir küme olarak kabul edildiği, daha sonra en yakın iki kümenin yeni bir kümede birleştirilip, küme sayısının bu şekilde her seferinde bir azaltıldığı yönteme gruplayıcı hiyerarşik yöntem denir. Oluşan küme yapıları "dendogram” adı verilen şekille gösterilebilir [14]. Küme sayısı konusunda ön bilgi varsa veya uygun küme sayısına karar verilmiş ise bu durumda, çok uzun zaman alan hiyerarşik yöntemler yerine hiyerarşik olmayan 
yöntemler kullanılmaktadır [15]. Hiyerarşik olmayan kümeleme yönteminde değişkenlerden ziyade nesneler gruplandırılır ve bu nesneler $\mathrm{K}$ adet kümeye ayrılır. Küme sayısı K başlangıçta belirlenebileceği gibi kümeleme sürecine bağlı olarak da ortaya çıkabilir [14].

Çalışmada kullanılan İki Aşamalı Kümeleme Yöntemi ise Ward'ın Minimum Varyans yöntemi ile K-Means yönteminden oluşan hibrid bir yaklaşımdır [16]. Yöntem optimum küme sayısını kendi belirlemektedir. Bunun için BIC (Schwarz's Bayesian Information Criterion) ya da AIC (Akaike's Information Criterion) yöntemlerini kullanır [17].

Yöntem pek çok disiplinden pek çok araştırmacı tarafından kullanım alanı bulmuştur. Örneğin Jiang vd. [18] yöntemi üç ayrı veri setindeki sapan değerleri tespit etmek için kullanmış ve metodun işlerliğinin son derece iyi olduğunu raporlamışlardır. Choi vd. [19] ise bir kablosuz algılayıcı ağındaki kurulumu iki aşamalı kümeleme yöntemi ile yeniden yapılandırmış, bu yapılandırma sayesinde önemli ölçüde enerji tasarrufu sağlanmıştır. Fasanghari vd. [20] aynı yöntemi kullanarak büyük organizasyonlarda bilişim teknolojileri yönetimini ilgilendiren önemli konuları belirlemiş, bu yolla organizasyonlara alanda üzerinde durulması gereken yönetim araçları hakkında büyük bir resim sunmuşlardır. Bir İran bankasının verilerini kullanan Namvar vd. [21] ise banka müşterilerinden oluşan veri setini yine iki aşamalı kümeleme yöntemi kullanarak ilk aşamada KMeans kümeleme ile müşteri değeri (RFM) açısından kümelemiş, ikinci aşamada da her bir kümeyi yine demografik verileri kullanarak ayrı kümelere bölmüş ve son olarak müşteri yaşam boyu değerini (LTV) kullanarak yeni bir müşteri profili oluşturmuştur. Farklı bir alanda çalışma yapan Tang [22] da 1 y1l boyunca 5 popüler web sayfasından 5 ayrı konuda (Spor, Bilim, Teknoloji, Finans ve Eğlence) elde ettiği haberler üzerinde olay tanımlama ve izleme analizinde iki aşamalı kümeleme yöntemi kullanarak haberleri sıralamıştır. Sonuçlar kullanılan yöntemin son derece başarılı olduğunu, yapılan sıralamaların bağımsız kuruluşlarca yapılan sırlamalar ile örtüştüğünü göstermiştir.

\section{UYGULAMA (APPLICATION)}

\section{1. Örneklem Seçimi ve Verilerin Toplanması (Sampling and Data Collection)}

Çalışma için İstanbul Sanayi Odası'nın 2012 yılında yayınladığı "İlk 500 Sanayi Kuruluşu” listesinde bulunan firmalardan Borsa İstanbul'da işlem gören rastgele 90 tanesi seçilmiştir. $\mathrm{Bu}$ firmaların Kamuyu Aydınlatma Platformu'nun (KAP) web sayfasında yayınlanmış olan 2013 y1lı finansal tabloları üzerinden belirlenen finansal oranları IBM SPSS Statistics 21 yazılımı ile "İki Aşamalı Kümeleme" yöntemi kullanılarak kümeleme analizi yapılmıştır. İki Aşamalı Kümeleme yönteminin seçilmesinin iki önemli nedeni bulunmaktadır. Birincisi yöntemin veriler 1şığında K-Means yönteminin gerektirdiği küme sayısını hesaplaması, ikincisi ise hem metrik hem de kategorik değişkenleri bir arada analiz edebilme yetisidir.

Firmaların finansal tablolarından elde edilen oranlar için CAMELS sinıflandırması temel alınarak maksimum olması istenen oranlar seçilmiştir [23]. Firma isimleri gizli tutulmakta, analizlerde ve sonuçlar kısmında bu isimler kodlanarak belirtilmektedir. Çalışmada kullanılan oranlar aşağıdaki tabloda gösterilmektedir.

Tablo 1. Çalışmada kullanılan finansal oranlar (The Financial Ratios used)

\begin{tabular}{|c|c|}
\hline Kod & Finansal Oran \\
\hline FOO1 & Net Kâr / Aktif \\
\hline FOO2 & Net Kâr / Öz kaynak \\
\hline FOO3 & Vergi Öncesi Kâr / Aktif \\
\hline FO04 & Net Kâr / Ödenmiş Sermaye \\
\hline FO05 & Dönen Varlik / Toplam Varlık \\
\hline FO06 & Dönen Varlık / Kısa Vadeli Borç \\
\hline FO07 & Finansal Varlı/ Toplam Aktif \\
\hline FO08 & Öz kaynak/Toplam Aktif \\
\hline FO09 & (Öz kaynak - Duran Varlık) / Toplam Aktif \\
\hline FO10 & Net Satıș / Ticari Alacaklar \\
\hline FO11 & Faaliyet Kârı / Net Satış \\
\hline FO12 & Net Kâr / Net Satı̧s \\
\hline
\end{tabular}

Çalışmada belirlenmiş olan 90 firmanın ait oldukları sektörler ise aşağıdaki tabloda görülmektedir:

Tablo 2. Firmaların ait oldukları sektörler (Sectors of the firms)

\begin{tabular}{|l|c|c|}
\hline Sektör & Firma Sayısı & Yüzde \\
\hline Cam, Çimento, Toprak Ürünleri & 19 & 21,1 \\
\hline Elektrik-Elektronik & 7 & 7,8 \\
\hline Enerji & 5 & 5,6 \\
\hline Glda & 12 & 13,3 \\
\hline Kimya, Petrol, Lastik ve Plastik & 19 & 21,1 \\
\hline Metal & 9 & 10,0 \\
\hline Otomotiv & 11 & 12,2 \\
\hline Tekstil, Hazır Giyim ve Deri & 3 & 3,3 \\
\hline Ticaret & 5 & 5,6 \\
\hline Toplam & 90 & 100 \\
\hline
\end{tabular}

\subsection{Verilerin Analizi (Analysis of Data)}

Oranlar elde edilerek IBM SPSS Statistics 21 yazılımında "İki Aşamalı Kümeleme" analizi uygulanmıştır. Uygulamada ilk olarak belirlenen 12 adet finansal oran ile 90 adet firmanın oluşturduğu matris elde edilmiştir. Bu noktadan sonra yapılan analizlerin seyrine göre daha iyiyi elde etmek amacıyla farklı varyasyonlar denenmiştir.

Birinci denemede, tüm veriler analiz kapsamına alınmış ve iki ayrı küme elde edilmiştir. Birinci kümede finansal oranları daha yüksek olan 87 , ikinci kümede ise finansal oranları daha düşük olan 3 firma içeren 2 adet küme ortaya çıkmıştır. Kümelerin firma sayılarını, küme üyeliklerini ve belirleyici oranların her bir küme için ortalama ve standart sapma değerlerini veren tablolar aşağıdaki gibidir. 
Tablo 3. Uyg. 1-Kümelerin firma sayıları ve üyelikleri (Number of firms and cluster memberships for App. 1)

\begin{tabular}{|l|c|c|l|}
\hline & Firma Sayıs (N) & Yüzde & Firmalar \\
\hline Küme 1 & 87 & 96,7 & Diğerleri \\
\hline Küme 2 & 3 & 3,3 & 43,52 ve 74 \\
\hline Toplam & 90 & 100 & \\
\hline
\end{tabular}

Tablo 4. Uyg. 1-Oranların kümeler için ortalama ve standart sapma değerleri

(Mean and standard deviation values of the ratios for App. 1)

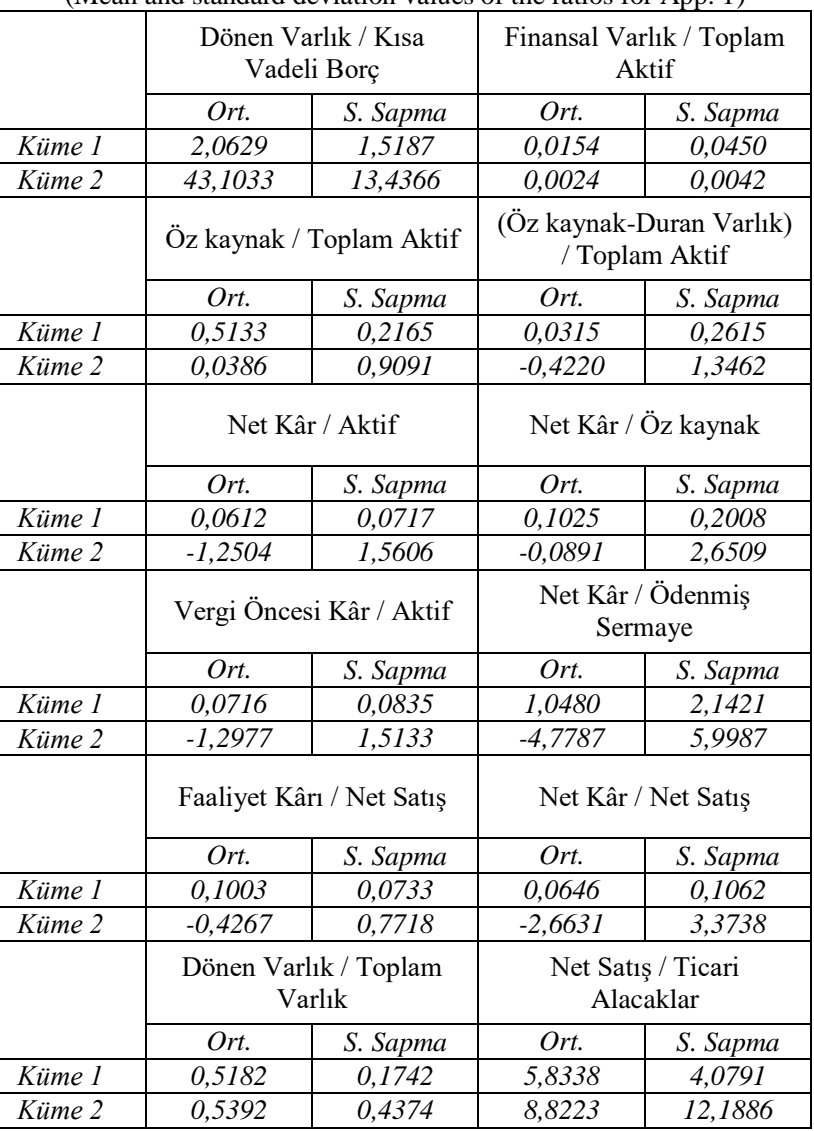

12 faktör, 90 birimle yapılan analiz, Silhouette küme içi bitişme ve kümeler arası ayrışma (kohezyon ve separasyon) ölçeğine göre oldukça iyi sayılabilecek kalitededir $(\approx 0,70)$.Ayrıca mevcut faktörler dâhilinde analizin ortaya çıkan sonucunun belirleyici faktörleri de aşağıdaki şekilde gösterilmiştir.

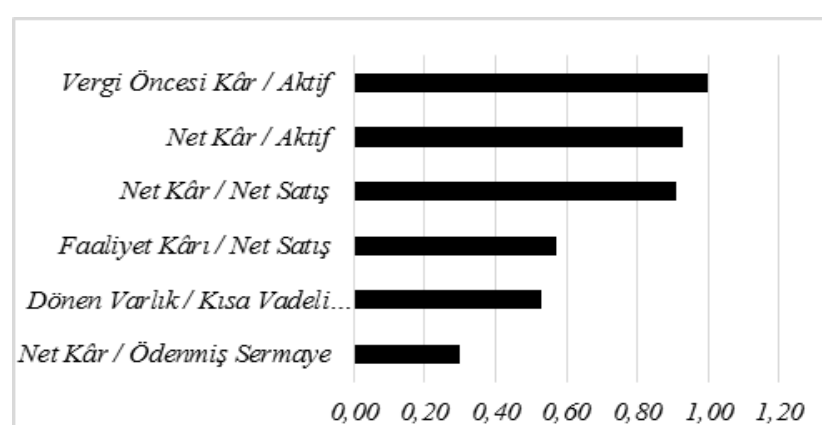

Şekil 1. Uyg. 1-Belirleyici faktörler (Predictor importance for App. 1)
Ortaya çıkan sonuç gerek küme sayısı gerekse sayıların dağılımı bağlamında fikir verici olmadığ üzerinde birtakım ayıklama işlemi yapılması, varsa gürültülü verilerin elenmesi amaçlanmıştır. Bu bağlamda mevcut 12 finansal oranın her birinin firmalar için anlamlı farklılık arz etme durumunun tespitinin yapılmasına karar verilmiştir. Yapılan ANOVA testinin sonucunda istatistiksel olarak anlamlı farklılık arz eden ve etmeyen faktörler aşağıdaki gibidir.

Tablo 5. Uygulama 1-ANOVA testi sonuçları (Results of ANOVA for Application 1)

\begin{tabular}{|l|l|c|}
\hline Kod & Finansal Oran & Anlamlılı (Sig.) \\
\hline FO01 & Net Kâr / Aktif & 0,000 \\
\hline FO02 & Net Kâr / Öz kaynak & 0,410 \\
\hline FO03 & Vergi Öncesi Kâr / Aktif & 0,000 \\
\hline FO04 & Net Kâr / Ödenmiş Sermaye & 0,379 \\
\hline FO05 & Dönen Varlık / Toplam Varlık & 0,957 \\
\hline FO06 & Dönen Varlık / Klsa Vadeli Borç & 0,000 \\
\hline FO07 & Finansal Varlık / Toplam Aktif & 0,483 \\
\hline FO08 & Öz kaynak / Toplam Aktif & 0,015 \\
\hline FO09 & (Öz kaynak - Duran Varlı) / Toplam & 0,059 \\
\hline FO10 & Net Satış / Ticari Alacaklar & 0,000 \\
\hline FO11 & Faaliyet Kârı / Net Satış & 0,001 \\
\hline FO12 & Net Kâr / Net Satış & 0,000 \\
\hline
\end{tabular}

Tabloda görüldüğü gibi çalışmanın başında belirlenmiş olan 12 adet finansal orandan 5 adedinin mevcut veri seti üzerinde istatistiksel olarak anlamlı farklılık göstermediği ortaya çıkmıştır. Bundan sonraki analizler anlamlı farklılık arz eden 7 adet finansal oran üzerinden yapılmıştır.

İkinci denemede, ilk denemedeki "İki Aşamalı Kümeleme Analizi”, ANOVA testi yapildıktan sonra elde kalan 7 adet finansal oran ile yapılmıştır. Yapılan analiz sonucunda birinci kümede finansal oranları daha yüksek olan 88 , ikinci kümede ise finansal oranları daha düşük olan 2 firma içeren 2 adet küme ortaya çıkmıştır. Kümelerin firma sayılarını, küme üyeliklerini ve belirleyici oranların her bir küme için ortalama ve standart sapma değerlerini veren tablolar aşağıdaki gibidir.

Tablo 6. Uyg. 2-Kümelerin firma sayıları ve üyelikleri (Number of firms and cluster memberships for App. 2)

\begin{tabular}{|l|c|c|l|}
\hline & Firma Sayısı (N) & Yüzde & Firmalar \\
\hline Küme 1 & 88 & 97,8 & Diğerleri \\
\hline Küme 2 & 2 & 2,2 & 43 ve 74 \\
\hline Toplam & 90 & 100 & \\
\hline
\end{tabular}


Tablo 7. Uyg. 2-Oranların kümeler için ortalama ve standart sapma değerleri

(Mean and standard deviation values of the ratios for App. 2)

\begin{tabular}{|c|c|c|c|c|}
\hline & \multicolumn{2}{|c|}{ Net Kâr / Aktif } & \multicolumn{2}{|c|}{ Vergi Öncesi Kâr / Aktif } \\
\hline & Ort. & S. Sapma & Ort. & S. Sapma \\
\hline Küme 1 & 0,0592 & 0,0738 & 0,0691 & 0,0862 \\
\hline \multirow[t]{3}{*}{ Küme 2} & $-1,8165$ & 1,7170 & $-1,8730$ & 1,6108 \\
\hline & \multicolumn{2}{|c|}{$\begin{array}{l}\text { Dönen Varlık / Kısa } \\
\text { Vadeli Borç }\end{array}$} & \multicolumn{2}{|c|}{ Öz kaynak / Toplam Akti } \\
\hline & Ort. & S. Sapma & Ort. & S. Sapma \\
\hline Küme 1 & 2,0458 & 1,5185 & 0,5068 & 0,2237 \\
\hline \multirow[t]{3}{*}{ Küme 2} & 64,3772 & 90,9390 & 0,0868 & 1,2803 \\
\hline & \multicolumn{2}{|c|}{ Faaliyet Kârı / Net Satış } & \multicolumn{2}{|c|}{ Net Kâr / Net Satış } \\
\hline & Ort. & S. Sapma & Ort. & S. Sapma \\
\hline Küme 1 & 0,0996 & 0,0732 & 0,0620 & 0,1084 \\
\hline \multirow[t]{3}{*}{ Küme 2} & $-0,6600$ & 0,9301 & $-3,9120$ & 3,6616 \\
\hline & \multicolumn{2}{|c|}{$\begin{array}{l}\text { Net Satış / Ticari } \\
\text { Alacaklar }\end{array}$} & & \\
\hline & Ort. & S. Sapma & & \\
\hline Küme 1 & 5,8100 & 4,0617 & & \\
\hline Küme 2 & 11,3651 & 16,0726 & & \\
\hline
\end{tabular}

Burada da 7 faktör ve 90 birimle yapılan analiz, Silhouette küme içi bitişme ve kümeler arası ayrışma (kohezyon ve separasyon) ölçeğine göre çok daha iyi kalitededir $(\approx 0,80)$. Zira gürültülü veriler elenmiş, veri seti daha berrak bir görünüme ulaşmıştır. Burada da mevcut faktörler dâhilinde analizin ortaya çıkan sonucunun belirleyici faktörleri aşağıdaki şekilde gösterilmiştir.

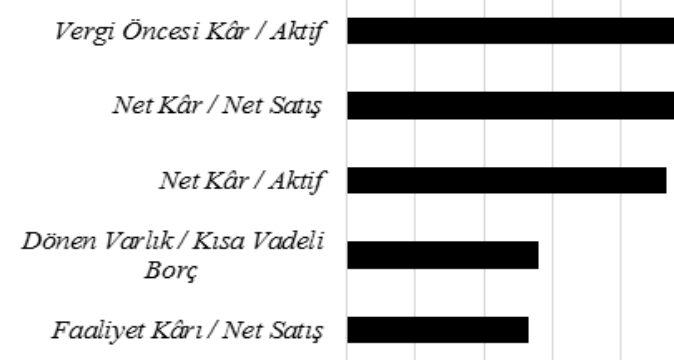

$\begin{array}{lllllll}0,00 & 0,20 & 0,40 & 0,60 & 0,80 & 1,00 & 1,20\end{array}$

Şekil 2. Uyg. 2-Belirleyici faktörler (Predictor importance for App. 2)

İki Aşamalı Kümeleme Analizinin bir özelliği olarak küme sayısının denetimsiz olarak belirlenmesinden dolayı program mevcut veri seti için her iki denemede de 2 küme belirlemiştir. Küme sayısına müdahale ederek daha homojen olan en az 2 küme elde edebilmek amaciyla çeşitli küme sayıları denenmiştir.

Üçüncü denemede, ikinci denemedeki veri seti ve faktörler bu kez denetimli bir nitelik kazandırılmak suretiyle 3,4 ve 5 küme oluşacak biçimde analiz edilmiştir. Sonuçta 3 kümeli analizde firma sayıları 42, 46 ve 2 olan kümeler elde edilmiştir. 4 ve 5 kümeli analizlerde ise oluşturulan 4. ve 5. kümelerin 1'er elemanlı zorlama kümeler olduğu, doğal desenler yaratmadığı anlaşılmıştır. 3 kümeli analizin kümelerinin firma sayılarını, küme üyeliklerini ve belirleyici oranların her bir küme için ortalama ve standart sapma değerlerini veren tablolar aşağıdaki gibidir.

Tablo 8. Uyg. 3-Kümelerin firma sayıları ve üyelikleri (Number of firms and cluster memberships for App. 3)

\begin{tabular}{|c|c|c|c|}
\hline & Firma Sayısı & Yüzde & Firmalar \\
\hline Küme 1 & 42 & 46,7 & $\begin{array}{l}1,3,5,7,10,11,12,17,18, \\
19,24,25,27,28,29,32, \\
36,39,40,41,44,45,48, \\
49,51,54,55,58,59,60, \\
61,62,66,67,69,71,75, \\
77,78,80,81 \text { ve } 85\end{array}$ \\
\hline Küme 2 & 46 & 51,1 & $\begin{array}{l}2,4,6,8,9,13,14,15,16, \\
20,21,22,23,26,30,31, \\
33,34,35,37,38,42,46, \\
47,50,52,53,56,57,63, \\
64,65,68,70,72,73,76, \\
79,82,83,84,86,87,88,\end{array}$ \\
\hline Küme 3 & 2 & 2,2 & 43 ve 74 \\
\hline Toplam & 90 & 100 & \\
\hline
\end{tabular}

Tablo 9. Uyg. 3-Oranların kümeler için ortalama ve standart sapma değerleri

(Mean and standard deviation values of the ratios for App. 3)

\begin{tabular}{|c|c|c|c|c|}
\hline & \multicolumn{2}{|c|}{ Net Kâr / Aktif } & \multicolumn{2}{|c|}{ Vergi Öncesi Kâr / Aktif } \\
\hline & Ort. & S. Sapma & Ort. & S. Sapma \\
\hline Küme 1 & 0,1020 & 0,0708 & 0,1226 & 0,0815 \\
\hline Küme 2 & 0,0201 & 0,0518 & 0,0203 & 0,0568 \\
\hline \multirow[t]{3}{*}{ Küme 3} & $-1,8165$ & 1,7170 & $-1,8730$ & 1,6108 \\
\hline & \multicolumn{2}{|c|}{$\begin{array}{c}\text { Dönen Varlık / Kısa } \\
\text { Vadeli Borç }\end{array}$} & \multicolumn{2}{|c|}{ Öz kaynak / Toplam Aktif } \\
\hline & Ort. & S. Sapma & Ort. & S. Sapma \\
\hline Küme 1 & 2,8533 & 1,8546 & 0,6955 & 0,1154 \\
\hline Küme 2 & 1,3084 & 0,3995 & 0,3345 & 0,1452 \\
\hline \multirow[t]{3}{*}{ Küme 3} & 64,3772 & 90,9390 & 0,0868 & 1,2803 \\
\hline & \multicolumn{2}{|c|}{ Faaliyet Kârı / Net Satış } & \multicolumn{2}{|c|}{ Net Kâr / Net Satış } \\
\hline & Ort. & S. Sapma & Ort. & S. Sapma \\
\hline Küme 1 & 0,1391 & 0,0781 & 0,1169 & 0,0788 \\
\hline Küme 2 & 0,0635 & 0,0450 & 0,0118 & 0,1081 \\
\hline \multirow[t]{3}{*}{ Küme 3} & $-0,6600$ & 0,9301 & $-3,9120$ & 3,6616 \\
\hline & \multicolumn{2}{|c|}{$\begin{array}{c}\text { Net Satış / Ticari } \\
\text { Alacaklar }\end{array}$} & & \\
\hline & Ort. & S. Sapma & & \\
\hline Küme 1 & 4,6377 & 2,1226 & & \\
\hline Küme 2 & 6,8804 & 5,0335 & & \\
\hline Küme 3 & 11,3651 & 16,0726 & & \\
\hline
\end{tabular}

Veri setinin en berrak haline müdahale edilince küme kalitesi de düşmüş, Silhouette küme içi bitişme ve kümeler arası ayrışma (kohezyon ve separasyon) ölçeğinin değeri azalmıştır $(\approx 0,50)$. Analizin belirleyici faktörler ise Şekil 3 'te gösterilmektedir.

Üçüncü deneme için kullanılan 7 faktör, uygulamaya alınmış olan firmalar için ANOVA testine tabi tutulmuş, sonuçta tüm faktörlerin istatistiksel olarak anlamlı ve güçlü farklılık gösterdiği ortaya çıkmıştır (7 faktörün her biri için Sig. = 0,000). Bununla beraber ANOVA'nın bir Post Hoc testi olan Scheffe analizinde 3 kümenin kendi içerisindeki istatistiksel olarak anlamlı farklılıklar görülebilmektedir. Buna göre 2. denemede, yani çalışmanın en doğal kümeleme analizinde 88 elemanlı 1 . kümeyi oluşturan; 3 . denemede müdahale edilerek 42 ve 46 elemanlı iki kümeye ayrılmış olan bu denemede 7 adet 
faktörün çoğunluğunda 1 ve 2 numaralı kümeler arasında istatistiksel olarak anlamlı farklılık olmadığ çıkmıştır. Buna dair sonuçlar Tablo 10’da görülmektedir.

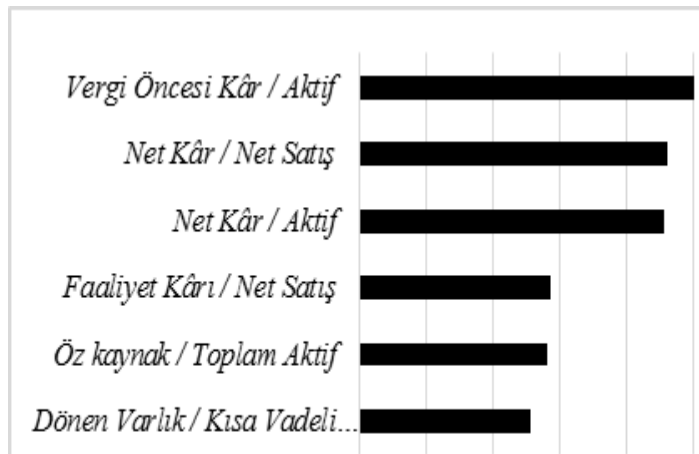

$\begin{array}{lllllll}0,00 & 0,20 & 0,40 & 0,60 & 0,80 & 1,00 & 1,20\end{array}$

Şekil 3. Uyg. 3-Belirleyici faktörler (Predictor importance for App. 3)

Tablo 10. Uyg. 3-ANOVA Post Hoc Scheffe testi (ANOVA Post-Hoc Scheffe test results for App. 3)

\begin{tabular}{|c|c|c|c|}
\hline Faktör & $\begin{array}{c}\text { Küme } \\
\text { (İncelenen) }\end{array}$ & $\begin{array}{c}\text { Küme } \\
\text { (Referans) }\end{array}$ & Sig. \\
\hline \multirow{6}{*}{ Net Kâr / Aktif } & \multirow[t]{2}{*}{1} & 2 & 0,147 \\
\hline & & 3 & 0,000 \\
\hline & \multirow[t]{2}{*}{2} & 1 & 0,147 \\
\hline & & 3 & 0,000 \\
\hline & \multirow[t]{2}{*}{3} & 1 & 0,000 \\
\hline & & 2 & 0,000 \\
\hline \multirow{6}{*}{ Vergi Öncesi Kâr / Aktif } & \multirow[t]{2}{*}{1} & 2 & 0,041 \\
\hline & & 3 & 0,000 \\
\hline & \multirow[t]{2}{*}{2} & 1 & 0,041 \\
\hline & & 3 & 0,000 \\
\hline & \multirow[t]{2}{*}{3} & 1 & 0,000 \\
\hline & & 2 & 0,000 \\
\hline \multirow{6}{*}{$\begin{array}{l}\text { Dönen Varlık / Kısa Vadeli } \\
\text { Borç }\end{array}$} & \multirow[t]{2}{*}{1} & 2 & 0,763 \\
\hline & & 3 & 0,000 \\
\hline & \multirow[t]{2}{*}{2} & 1 & 0,763 \\
\hline & & 3 & 0,000 \\
\hline & \multirow[t]{2}{*}{3} & 1 & 0,000 \\
\hline & & 2 & 0,000 \\
\hline \multirow{6}{*}{ Öz kaynak / Toplam Aktif } & \multirow[t]{2}{*}{1} & 2 & 0,000 \\
\hline & & 3 & 0,000 \\
\hline & \multirow[t]{2}{*}{2} & 1 & 0,000 \\
\hline & & 3 & 0,201 \\
\hline & \multirow[t]{2}{*}{3} & 1 & 0,000 \\
\hline & & 2 & 0,201 \\
\hline \multirow{6}{*}{ Net Satış / Ticari Alacaklar } & \multirow[t]{2}{*}{1} & 2 & 0,053 \\
\hline & & 3 & 0,099 \\
\hline & \multirow[t]{2}{*}{2} & 1 & 0,053 \\
\hline & & 3 & 0,351 \\
\hline & \multirow[t]{2}{*}{3} & 1 & 0,099 \\
\hline & & 2 & 0,351 \\
\hline \multirow{6}{*}{ Faaliyet Kârı / Net Satış } & \multirow[t]{2}{*}{1} & 2 & 0,013 \\
\hline & & 3 & 0,000 \\
\hline & \multirow[t]{2}{*}{2} & 1 & 0,013 \\
\hline & & 3 & 0,000 \\
\hline & \multirow[t]{2}{*}{3} & 1 & 0,000 \\
\hline & & 2 & 0,000 \\
\hline \multirow{6}{*}{ Net Kâr / Net Satış } & \multirow[t]{2}{*}{1} & 2 & 0,478 \\
\hline & & 3 & 0,000 \\
\hline & 2 & 1 & 0,478 \\
\hline & & 3 & 0,000 \\
\hline & 3 & 1 & 0,000 \\
\hline & & 2 & 0,000 \\
\hline
\end{tabular}

\section{BULGULAR (FINDINGS)}

Yapılan 3 farklı kümeleme analizi sonucunda şu çıkarımlar yapılabilir:

Birinci uygulamada analize dâhil edilen 12 faktör (finansal oran) bağlamında elde edilen 2 küme incelendiğinde bu 12 faktörün 9 tanesinde (Net Kâr/Aktif, Vergi Öncesi Kâr/Aktif, Öz kaynak/Toplam Aktif, Faaliyet Kârı/Net Satış, Net Kâr/Net Satış, Net Kâr/Öz kaynak, Net Kâr/Ödenmiş Sermaye, Finansal Varlık/Toplam Aktif, [Öz kaynak-Duran Varlık]/Toplam Aktif) 1 numaralı kümeye ait firmaların, 3 tanesinde (Dönen Varlık/Kısa Vadeli Borç, Net Satış/Ticari Alacaklar, Dönen Varlık/Toplam Varlık,) ise 2 numaralı kümeye ait firmaların daha iyi finansal oranlara sahip oldukları söylenebilir. Genel olarak kârlılık oranlarında ilk kümeye dâhil firmaların daha yüksek performanslara sahip olduğu, ikinci kümedeki firmaların ise düşük kârlarla ya da zarar ederek yılı kapattıkları söylenebilir.

Verilerde temizleme yapıldıktan sonra elde edilen 7 faktörlü ikinci uygulamada elde edilen yine 2 kümeye bakıldığında analize dâhil edilen 7 faktörün 5 tanesinde (Net Kâr/Aktif, Vergi Öncesi Kâr/Aktif, Öz kaynak/Toplam Aktif, Faaliyet Kârı/Net Satış, Net Kâr/Net Satış) 1 numaralı kümeye ait firmaların, 2 tanesinde (Dönen Varlık/Kısa Vadeli Borç, Net Satış/Ticari Alacaklar) ise 2 numaralı kümeye dâhil olan firmaların daha iyi finansal oranlara sahip oldukları söylenebilir.

Son olarak veri setine müdahale edilerek 3 kümeli olmas1 istenen üçüncü uygulamada en çok göze çarpan konu çalışılan 90 firma için 1 ve 2 numaralı kümelerde 7 adet faktörün büyük bir çoğunluğunda istatistiksel olarak anlamlı farklılık gözlenememesi olmuştur (Gözlenen farklılıkların da gücü son derece düşüktür). Bunun nedeni bir önceki uygulamada doğal olarak ortaya çıkan 88 elemanlı 1 numaralı kümenin ikiye bölünmesi sonucunda anlamlı bir ayrışma olamamasıdır. Bunu Post Hoc Testi ortaya koymuştur. Bununla birlikte finansal oranların faktörler bazında kümelere dağılımı bir önceki uygulamanın verdiği dağılımla aynı çıkmıştır. Yani 3 numaralı kümeye ait firmaların oranları 2 faktörde (Dönen Varlık/Kısa Vadeli Borç, Net Satış/Ticari Alacaklar) yüksek çıkarken diğer 5 faktörde (Net Kâr/Aktif, Vergi Öncesi Kâr/Aktif, Öz kaynak/Toplam Aktif, Faaliyet Kârı/Net Satış, Net Kâr/Net Satış) 1 ve 2 numaralı kümelere ait firmaların finansal oranları yüksek çıkmıştır.

\section{SONUÇ VE ÖNERİLER (CONCLUSION AND SUGGESTIONS)}

Firmaların finansal durumları, mevcut yapıları ve gelecekteki faaliyetleri açısından paydaşlar için çok büyük önem arz etmektedir. Firmaların likidite, finansal yapı, devir hızı ve kârlılık durumlarını gösteren bu oranlar 
sektörlere göre farklılıklar arz etse de bu çalıșmada bir standart sağlamak maksadıyla örneklem seçiminde de belirtildiği gibi "maksimize edilmesi beklenen" (çoğunluğu kârlılık oranları) oranlar seçilmiş ve sonraki işlemler de buna göre yapılmıştır.

Uygulamaların sonuçlarında oranları daha düşük olan firmaların genellikle yılı zararla kapatmaları nedeniyle kârlılık oranlarının negatif olmasından dolayı ayrı bir küme oluşturdukları anlaşılmıştır.

Sonuçlar ve ortaya çıkan görüntü muhatap firmaların kendileri başta olmak üzere pek çok paydaş için önem arz etmektedir. Tek dönem için yapılan bu çalışmaya benzer bir uygulama firmaların yıllar içerisindeki durumlarını görmek adına belirli dönemler için yapılabilir. Aynı şekilde farklı analiz teknikleri bir araya getirilerek hibrid uygulama ve analizlerle daha etkin ve berrak sonuçlara ulaşılabilir, sonuçlar arası validasyon sağlanır.

\section{KAYNAKLAR (REFERENCES)}

[1] Internet: Muhasebe Türk - Neden Halka Arz? (2007), http://muhasebeturk.org/borsa-piyasa-finans-menkul-kiymetlerimkb/429-temel-borsa-bilgileri/1026-neden-halka-arz-edilir.html, 8.2.2014.

[2] A. Damodaran, Investment Valuation: Tools and Techniques for Determining the Value of Any Asset. New York: Wiley, 2012.

[3] E. Birgili \& M. Düzer, "Finansal Analizde Kullanılan Oranlar ve Firma Değeri İlişkisi: İMKB'de Bir Uygulama”, Muhasebe ve Finansman Dergisi, (46), 74-83, 2010 Nisan.

[4] K. Chen \& T. Shimerda, “An Empirical Analysis of Useful Financial Ratios", Financial Management, 10(1), 51-60, 1981.

[5] İ. Türker, Türkiye'de Uluslararası Finansal Raporlama Standartları (UFRS) Paralelinde Yapılan Düzenlemelerin Finansal Tablo Kullanıcıları Üzerindeki Muhtemel Etkileri, Doktora Tezi, İstanbul Üniversitesi Sosyal Bilimler Enstitüsü, 2009.

[6] U. Mısırlığlu, “İşletmelerde Finansal Performans Raporlaması",Mali Çözüm, 16(75), 2006.

[7] Ö. Akgüç, Mali Tablolar Analizi, İstanbul: Arayış Yayıncılık, 2006

[8] S. Besley \& E. Brigham, Essentials of Managerial Finance, United States of America: Thomson Southwestern Corporation, 2007.
[9] F. Çömlekçi, M. Yılancı, N. Erdoğan, S. Önce, S. Selimoğlu, E. Kaya, Muhasebe Denetimi ve Mali Analiz, Eskişehir: Anadolu Üniversitesi Açık öğretim Yayınları, 2004

[10] S. Siddiqui \& A. Siddiqui, Managerial Economics and Financial Analysis,India: New Age International Publishers, 2005.

[11] Ö. Usta, İşletme Finansı ve Finansal Yönetim, Ankara: Detay Yayınc1lık, 2008.

[12] Ş. Kalaycı, SPSS Uygulamalı Çok Değişkenli İstatistik Teknikleri, Ankara: Asil Yayın Dağıtım, 2010.

[13] D. Cengiz \& F. Öztürk, "Türkiye'de İllerin Eğitim Düzeylerine Göre Kümeleme Analizi İle İncelenmesi” Trakya Üniversitesi Sosyal Bilimler Dergisi, 14(1), 69-84, 2012 Haziran.

[14] R. Johnson \& D. Wichern, Applied Multivariate Statistical Analysis, New Jersey: Prentice-Hall, 2002

[15] M. Anderberg, Cluster Analysis for Applications, New York: Academic Press, 1973

[16] Ç. Taşkıı \& G. G. Emel, "Clustering Approaches in Data Mining and an Application with Kohonen Networks in Retailing Sector", Suleyman Demirel University the Journal of Faculty of Economics and Administrative Sciences, 15(3), 395-409, 2010.

[17] S. Savaş \& N. Topaloğlu, Veri Madenciliği Yöntemi ile GSM Şebekelerinin Performans Analizi, Gazi Üniversitesi Mühendislik ve Mimarlı Fakültesi Dergisi, 26(4), 741-751, 2011.

[18] Jiang M. F., S.S. Tseng, C.M. Su, Two Phase Clustering Process for Outliers Detection, Pattern Recognition Letters, 22, 691-700, 2001.

[19] Choi W., P. Shah, S.K. Das, A Framework for Energy-Saving Data Gathering Using Two-Phase Clustering in Wireless Sensor Networks, Proceedings of the First Annual International Conference on Mobile and Ubiquitous Systems: Networking and Services (MobiQuitous'04), 2004.

[20] Fasanghari, M., F.N. Eslami, M. Naghavi, IT Governance Standard Selection Based on Two Phase Clustering Method, Fourth International Conference on Networked Computing and Advanced Information Management, 2008

[21] Namvar, M., M.R. Gholamian, S.K. Abi, A Two Phase Clustering Method for Intelligent Customer Segmentation, 2010 International Conference on Intelligent Systems, Modelling and Simulation, 2010.

[22] Tang, Jung, Chinese Event Identification and Tracking Using Two Phase Clustering Algorithm, Journal of Convergence Information Technology, 6(3), 283-289, 2011.

[23] Y. T. Kaya, Türk Bankacılık Sektöründe CAMELS Analizi, Bankacıllk Düzenleme ve Denetleme Kurumu, Türkiye, 2001. 